\title{
Destabilizing the American Racial Order
}

\section{Citation}

Hochschild, Jennifer L., Vesla Weaver, and Traci Burch. 2011. Destabilizing the American racial order. Daedalus 140(2): 151-165.

\section{Published Version}

doi:10.1162/DAED_a_00084

\section{Permanent link}

http://nrs.harvard.edu/urn-3:HUL.InstRepos:8811856

\section{Terms of Use}

This article was downloaded from Harvard University's DASH repository, and is made available under the terms and conditions applicable to Open Access Policy Articles, as set forth at http:// nrs.harvard.edu/urn-3:HUL.InstRepos:dash.current.terms-of-use\#OAP

\section{Share Your Story}

The Harvard community has made this article openly available.

Please share how this access benefits you. Submit a story.

Accessibility 


\title{
Destabilizing the American Racial Order
}

\author{
Jennifer L. Hochschild, Vesla M. Weaver \& Traci Burch
}

JENNIFER L. HOCHSCHILD, a Fellow of the American Academy since 1996, is the Henry LaBarre Jayne Professor of Government, Professor of African and African American Studies, and Harvard College Professor at Harvard University.

VESLA M. WEAVER is an Assistant Professor of Politics at the University of Virginia.

TRACI BURCH is an Assistant Professor of Political Science at Northwestern University and a Research Professor at the American Bar Foundation.

( *See endnotes for complete contributor biographies.)
Since America's racial disparities remain as deeprooted after Barack Obama's election as they were before, it was only a matter of time until the myth of postracism exploded in our collective national face.

- Peniel Joseph, The Chronicle of Higher Education (July 27, 2009)

In electing me, the voters picked the candidate of their choice, not their race, which foreshadowed the historic election of Barack Obama in 2008. We've come a long way in Memphis, and ours is a story of postracial politics.

- Congressman Steve Cohen, Letter to the Editor, The New York Times (September 18, 2009)

Race is not going to be quite as big a deal as it is now; in the America of tomorrow ... race will not be synonymous with destiny.

- Ellis Cose, Newsweek (January 11, 2010)1
A re racial divisions and commitments in the United States just as deep-rooted as they were before the 2008 presidential election, largely eliminated, or persistent but on the decline? As the epigraphs show, one can easily find each of these pronouncements, among others, in the American public media. Believing any one of them - or any other, beyond the anodyne claim that this is "a time of transition" - is likely to be a mistake, since there will be almost as much evi- dence against as for it. Instead, it is more illumi- nating to try to sort out what is changing in the
(C) 2011 by the American Academy of Arts \& Sciences 
Destabi- American racial order, what persists

lizing the or is becoming even more entrenched,

American
Racial and what is likely to affect the balance

Order between change and continuity. That, at any rate, is what we propose to do

(if briefly) in this article.

Given space constraints, we focus on young adults. Even if we cannot fully disentangle the effects of age, historical era, and cohort, understanding this population is essential if we are to grasp what is and is not changing in the American racial order. We argue that younger cohorts of Americans were raised in a different racial context and think about and practice race differently than their older counterparts do. ${ }^{2}$ Older Americans are products of "the sixties" and its sequelae - namely, a rise in immigration, blacks' assertion of pride and dignity, whites' rejection of racial supremacy (at least in public), a slow opening of schools and jobs and suburbs to people previously excluded, and a shift in government policy from promoting segregation and hierarchy to promoting (at least officially) integration and equality. Now, however, new institutions and practices are moving into place: official records permit people to identify with more than one race, antidiscrimination policies are well established in schools and workplaces, and some non-whites hold influential political positions. The very meaning of race for most of the twentieth century - a few exhaustive and mutually exclusive groups into which one is born and in which one stays - is becoming less and less tenable. Immigration and interracial relationships have produced a set of people who do not fit conventional racial categories and who change their racial identity in different contexts. Today's young adults will move through adulthood with the knowledge that one need not be white in order to become the most powerful person in the world.

For these and other reasons, young Americans' racial attitudes are usually more liberal than those of older Americans, and their social networks are more intertwined. Race, while still predictive, is less able to determine a young adult's life chances and eventual socioeconomic status than ever before in American history. These changes in the views and behaviors of young people have the potential to produce a new American racial order - that is, if Americans take the political and policy steps needed to diminish barriers that still block the chances of too many young Americans. If residents of the United States make the right choices over the next few decades, the country could finally move toward becoming the society that James Madison envisioned in Federalist No. 10, one in which no majority faction - not even native-born European Americans - can dominate the political, economic, or social arena.

We are hardly the first to notice significant changes in young Americans; bookstores are full of volumes on "the new millennials." But we analyze destabilization of the racial order more systematically and theoretically than many others have done, and we add some distinctive elements. Following the work of government and social policy scholar Brenna Powell, we define a racial order as a society's widely understood and accepted system of beliefs, laws, and practices that organizes relationships among groups understood to be races or ethnicities. ${ }^{3}$ A racial order can be analyzed through five components: definition of a race or ethnicity; classification of individuals into races or ethnicities; groups' position relative to that of other groups; acts that are forbidden, permitted, or required; and social rela- 
tions among groups. All these components are changing - within individuals, between persons, among groups, and across society. Variations in the five components of the racial order may even be multiplicative in the sense that forms of instability interact to increase the momentum of transformation. Young adults are not only more likely to be immigrants and to marry across racial lines, they are also less committed to the cognitions, emotions, behaviors, and assumptions associated with the racial order of the civil rights era and its aftermath. If these new views and practices persist as young adults move through the life cycle, influencing the people growing up behind them, then the magnitude and pace of racial destabilization may increase at ever faster rates.

This image of a snowball gaining girth and speed as it tumbles down a hill does not, however, quite complete our argument. The racial terrain has roadblocks and boulders that can halt, deflect, or even explode the rolling snowball. Some of the least attractive features of the current American racial order have remained stable, and some may even be solidifying, especially among younger Americans. New groups - for instance, undocumented Latino immigrants or Muslim men may be moving into the old roles of "most disfavored." Extraordinarily high levels of police stops and incarceration among young black urban men deepen old racial barriers. Some features of the American racial order could even be solidifying because other features are becoming unstable. For example, advocacy groups may seek even greater group solidarity for fear that the dissolution of a unified group will worsen persistent race-based prohibitions or deplete the ability to defend against growing anti-immigrant discrimination. They may be right, since percep- tions and practices of racial distinctiveness are dissolving faster than groupbased hierarchy is being undone, potentially leaving the worst-off without supporters or even a language to challenge injustice.

On balance, the old racial order is being transformed - but how it is changing, how much, for whom, and to what effect is not easily discerned. Disaggregating the changes into five strands is, in our view, the best way to address these questions. Having done so, we are confident in predicting that racial attitudes, practices, and relative inequalities will be profoundly different for our children and grandchildren than they are for us. We anticipate, but we cannot confidently predict, that the gains will outweigh the costs. That result will depend largely on how the American political and social systems deal with the unintended consequences of these pending transformations.

Yo to the simple question, what is a race? to the simple question, what is a race? Figure 1 shows two forms used by major American universities on job applications for an assistant professorship during the mid-20oos. The University of California, Berkeley (left) aimed at precision through detail, while Pennsylvania State University (right) aimed at precision through minimalism. Both mix race and ethnicity on a single list; Berkeley adds the complications of ancestry while Penn State hints that its main interest lies in legal statuses with budgetary implications. Berkeley acknowledges both biological and cultural components of race; Penn State was silent on the culture/biology dimension.

These examples suggest that definitions of race are increasingly in flux returning us in some ways to the nineteenth and early twentieth centuries. As postmodernists have been pointing
Jennifer L.

Hochschild, Vesla M.

Weaver

\& Traci

Burch 


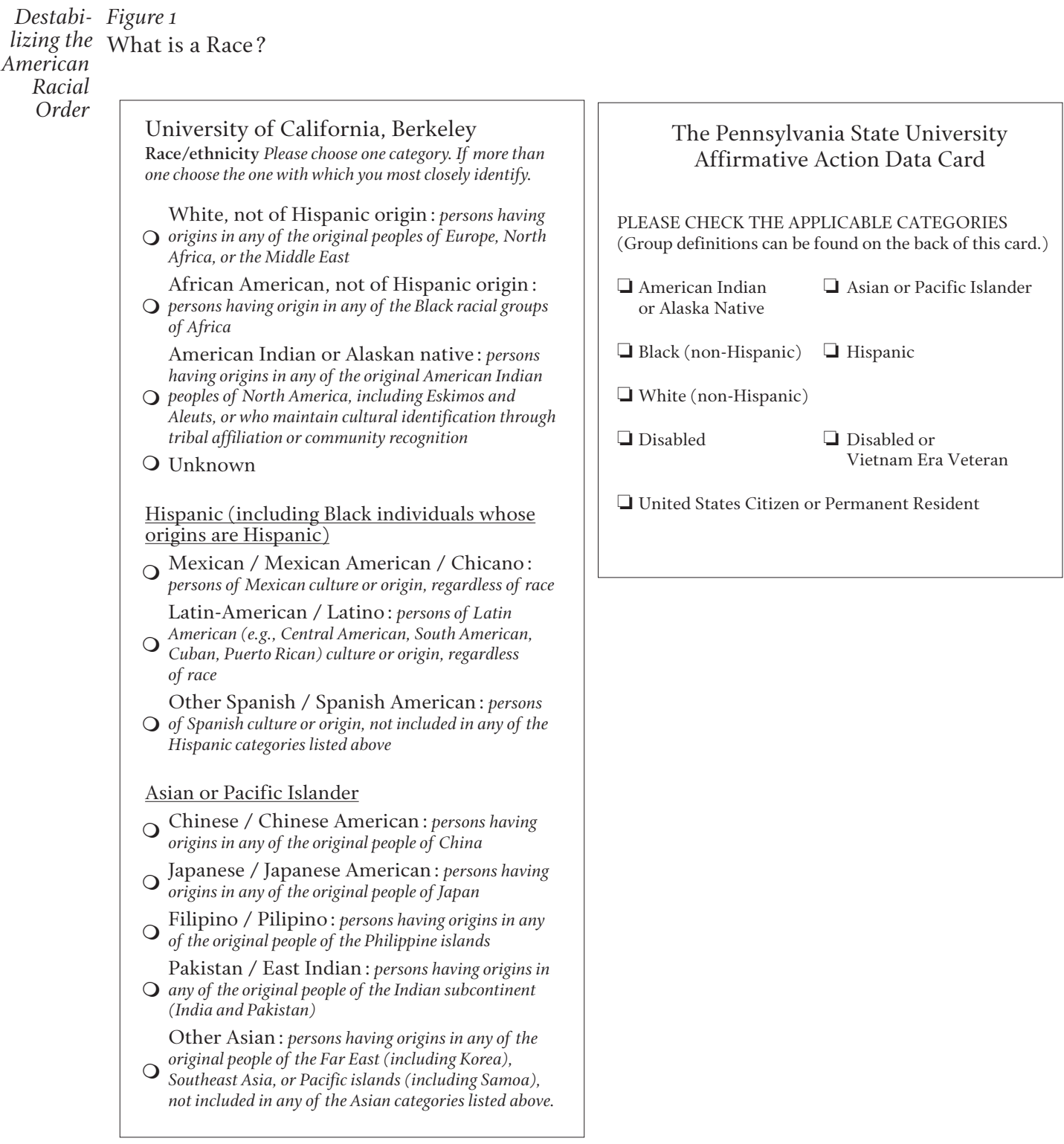

Source: Non-random sample of race/ethnicity forms used by various universities for job applications, collected by the authors in 2007 .

out for several decades, if the meaning of a term is unstable and nonconsensual, the social structures and practices built around it are much less solid than they appear to be. 4

Young adults are coming to realize that nominal racial groups do not have the solidity that they used to. In 2007 , for example, young black adults were more likely than older ones to agree that "Blacks today can no longer be thought of as a single race because the black community is so diverse." A year later, young black adults were slightly more likely to agree 


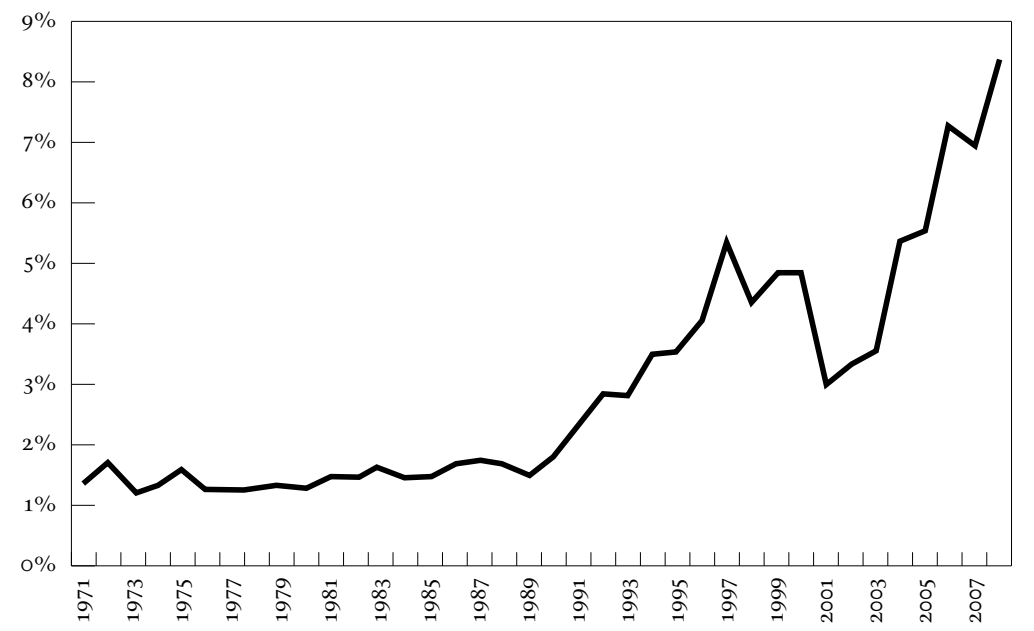

Data include only full-time students at four-year institutions, and only institutions with at least a 60 percent participation rate. Sample sizes range from 142,000 to 286,000 , in hundreds of institutions chosen by a complex stratification system. Source: Analysis completed for the authors by staff from the Higher Education Research Institute, Cooperative Institutional Research Program, Freshman Survey (Los Angeles: Graduate School of Education and Information Services, UCLA, various dates).

that "there is no general Black experience in America." 5 What counts as a race is no longer stable, and what characteristics a race has is becoming less clear, at least to the young.

As race itself is becoming more complicated, individuals' classifications are becoming less fixed. An increasing number of young Americans, for example, identify as multiracial or as some combination of conventionally defined races. Since 1971, a University of California, Los Angeles, survey of full-time, firstyear students at American colleges and universities has permitted respondents to choose more than one race. Figure 2 shows the pattern for all students, based on the weighted sample and including Hispanic as a "race" analogous to black, white, Asian, and American Indian. By 2007, more than 8 percent of students entering American higher education identified with more than one racial or ethnic group; the rise since 1990 has been uneven but unmistakable, and no evidence points to reversal.

That more young adults are choosing to identify as multiracial is no surprise, given that more are demographically mixed race. About half of the roughly seven million people who marked more than one race in the American Community Survey of 2009 were under age eighteen. Interracial mixture will continue to grow because marriages across group lines are increasing. Interracial marriages rose by 65 percent from 1990 to 2000 , and by 20 percent (from a higher base) over the next decade. Roughly 8 percent of all American marriages are across racial lines, and about 15 percent of new marriages in 2008 crossed group boundaries. Young adults are much more likely to marry across racial lines than are even the newly married among their 
Destabi- elders; 13 percent of currently married lizing the people under twenty-five have a spouse American
Racial of a different race. Intermarriage rates

Order drop steadily with increasing age, so that just 5 percent of married adults over age sixty have wed across group lines. ${ }^{6}$

In short, young Americans are not only facing a society in which the definition of a race is less and less clear, they are also increasingly less able or inclined to locate themselves within only one conventionally defined race. In one survey of students at highly selective colleges and universities, descriptions of ethnicity or ancestry included "gay Jewish $\mathrm{Cu}$ ban American," "adopted Chinese into an Indonesia [sic] and Filipino Family," "Mixed between American slave descendants and native Liberians, Liberian," and "usually Black, sometimes biracial."

As these survey responses suggest, immigration complicates individual classification in a different way. Many immigrants are reluctant to be categorized within the usual American racial nomenclature. Somalis, for example, care much more about religious identity and clan divisions than about American racial labels. As one student wrote in a school essay, "The Somalis that live here in the U.S. won't talk to each other until they know your tribe.... [E] very time I meet someone the first thought that comes to me is, do they hate you [sic] tribe?"7 Some immigrant or immigrant descendants change their racial identity when they move away from home: " $[\mathrm{R}]$ aised by White parents in a predominantly White town, I considered myself to be White.... In college new worlds of thought opened to me. Amid a boiling student struggle to create an Asian American studies program ... I began to see myself as an Asian American."8 Others identify with a different group from their parents, in a way that is hard for American-born blacks and whites to conceive of: "[R]ates of Mexican identification fall to 81 percent for secondgeneration children with only one Mexican-born parent."9 After all, if the racial or ethnic labels are essentially arbitrary from the vantage point of the person being labeled, why not let them vary?

$\mathrm{F}$ twentieth centuries, people of most Asian nationalities were excluded from the United States and denied citizenship even if they managed to immigrate. Some states prohibited Asians from owning certain kinds of property, and thousands of American citizens of Japanese descent were interned during World War II. But in recent decades, the relative socioeconomic status of Asian Americans and whites has been reversed, especially among young adults. Levels of higher education are the only indicator that we have space to report here. In 1980, close to 70 percent of young adult Asians had at least some college education; by 2009, that figure had risen even higher, to over 80 percent. The comparable figures for whites are just under 50 percent in 1980 and just over 60 percent in 2009 - an absolute gain, but not a relative gain compared with Asian Americans.

Although still educationally disadvantaged, even young adult African Americans and Hispanics are attaining more schooling than in 1980. The proportion of young adult blacks with at least some college has risen from just over 30 percent to almost 50 percent; for Latinos, the move was from less than 30 percent to about 45 percent. Thus, if post-high school education is a rough indicator of other measures of socioeconomic status, young Asian Americans are now better situated than all other groups and, if anything, gaining in advantages. At least compared with their situation a few decades ago, 
young adult blacks and Hispanics are better able to move into jobs requiring cognitive skills, but they remain considerably behind whites and Asians. A crucial question for the coming decades is how to avoid "black exceptionalism," in which all other non-white groups, possibly excepting unauthorized immigrants, improve their absolute and relative statuses, leaving blacks at the bottom. There are good reasons to believe that this outcome can be avoided - some articulated in this essay - but doing so will require concentrated efforts to address disparities of class as well as of race. Instability in relative group positions takes a different form in the political arena; here, African Americans have a distinct advantage over Asians and Hispanics. The data are not systematic, but multiple observations point to the idea that the role, or perhaps tone, of race in electoral politics is changing. Writer Darryl Pinckney observed a panel including Jesse Jackson, Jr., Al Sharpton, and Cornel West, all of whom emphasized "an alternate understanding of American history" that distinguishes blacks from other Americans. "And yet," Pinckney wrote, "I got a sense from the students around me that although they were saying thank you to the older style of black politics, it was for them very much a new day." 10 San Francisco District Attorney Kamala Harris makes roughly the same point: " $[\mathrm{O}]$ ur civil rights heroes fought so that we could be free to be anything we wanted. But today's plan of attack would not be to march; it would be to change legislation. We try to change the system from the inside." ${ }^{11}$ A young black candidate for the Boston City Council describes her generation as "coalition builders," able to "talk to and relate to other people.... I think the successes of our parents' generation have better positioned us - by being exposed to differ- ent opportunities, you're exposed to different people, different cultures, different perspectives."12

These quotations could be multiplied. More systematically, a survey conducted by the Joint Center for Political and Economic Studies found young black elected officials to have different, less conventionally Democratic political views from their elders, and to be more willing and able to appeal to voters outside their race. ${ }^{13}$ That finding suggests an increasing chance to develop new, broader constituencies - as well as to disrupt old assumptions and allegiances within minority populations.

The 2008 presidential election reinforces the sense that non-whites' political power is rising. Minorities were crucial to Obama's success both in the primaries and the general election, and their impact has made it clear that at least in some states, candidates no longer can focus only on white voters. In addition, Obama "scored an unprecedented victory among young Americans, taking 66 percent of the under-30 vote nationally." 14 Even controlling for education, race, party identification, and views about the economy and equity, age was significantly related to support for Obama's candidacy. ${ }^{15}$ If, as political scientists have consistently found, a person's earliest political experiences tend to shape their later commitments and attitudes, ${ }^{16}$ then young white voters may be more willing over the next few decades to support non-white candidates than their counterparts used to be, and young nonwhite voters may feel more efficacious in electoral politics than their older counterparts did.

It would be naive to imagine that race no longer matters in electoral politics one need only to look at the Senate or the set of governors to be disabused of that idea. Furthermore, black legislators
Jennifer L.

Hochschild, Vesla M. Weaver

\& Traci Burch 
Destabi- remain less successful in getting their lizing the bills passed. ${ }^{17}$ But mounting evidence American shows that opportunities for young black Order political candidates are improving, that black candidates have more flexibility in possible policy positions and strategies for appealing to voters, and that young voters of all races are increasingly willing to support some black candidates. While Asians have overtaken whites in educational attainment (and achievement), blacks are at least weakening whites' hold on political power.

U ntil the 1960s, whites had the widest array of permissions and the narrowest list of prohibitions; in legal terms, the civil rights movement and Great Society policies swept all that away. Social scientists should never make absolute statements and risk overlooking exceptions, but we can say that we have not been able to identify any current laws that permit or prohibit action based on race or ethnicity alone. (The Voting Rights Act and affirmative action policies come close to being exceptions, but they make distinctions by race or ethnicity with the purpose of benefiting rather than harming disadvantaged minorities.) This 1960s transformation of the legal structure underlying the American racial order made possible further destabilizations in the 2000s.

Nevertheless, some argue that, at times, state actions still uphold the old, precivil rights racial order. Evidence for this claim is most apparent in the criminal justice system, and most apparent for the young. Controlling for delinquency, black teens are twice as likely as whites to have experienced a police intervention by the tenth grade. A study of Chicago found that 20 percent of all sampled residents, but fully 70 percent of young black men, recalled being stopped by police in the past year. ${ }^{18}$ As one stu- dent puts it, "[T]hey'll pull me aside sometimes because they say I fit the description. Yeah. Young Black male. I always "fit the description."'19

Immigration is another arena in which official or quasi-official state policies tilt toward the old system of race-based prohibitions; again, young non-white men are disproportionately affected. Section 287 (g) of the 1996 immigration law "permit[s] designated ... local law enforcement... officers to perform immigration law enforcement functions." ${ }^{20}$ Even the institutionally cautious Government Accountability Office concludes, "Better Controls Needed over Program." It found that some local agencies have focused not on terrorism or serious crime as the program intended, but instead "used 287 (g) authority to process individuals for minor crimes, such as speeding." All local agencies lacked sufficient oversight, and most reported community concern that "use of program authority would lead to racial profiling and intimidation by law enforcement officers." 21

Section $287(\mathrm{~g})$ has an impact well beyond the small number of communities using it. By 2010, slightly over half of Latinos - a third of the native-born and seven-tenths of the foreign-born - worried that they or a close associate might be deported. A third claimed to know someone who had in fact been detained or deported within the past year. ${ }^{22}$

Perhaps most important, in 2010, Arizona passed a law that would permit the police to request proof of legal status after stopping someone for a traffic or other offense. The law is currently blocked by the courts on the grounds that it interferes with federal authority, but legislators in roughly twenty other states have suggested that they will introduce similar legislation.

Protecting citizens against crime, policing the borders, and guarding against 
terrorism are essential functions of government. But racial profiling, harassment of immigrants (and Muslim men), and the extremely high levels of incarceration of young black men reinforce old patterns of racial hostility and alienation, especially among teens and young adults. If group-based prohibitions persist, they could prevent the current destabilization of the old racial order from becoming a genuine transformation, at least for the people immersed in racially inflected modalities of control.

$\mathrm{O}$ vert expressions of stereotypes are declining in several ways. While many Americans, especially whites, still hold pejorative views of people of other races, the population overall identifies fewer sharp-edged group differences than in previous decades. Almost two-thirds of Americans, including seven-tenths of whites, agreed in 2007 that whites' and blacks' values have become "more similar" in the past decade. Asked if they "don't have much in common with people of other races," 24 percent of young adults "completely" disagreed in 19871988; that figure rose to 57 percent in 2009. (Among adults over age sixty, the proportions rose from 11 percent to 43 percent - a steeper climb, but to a lower summit.) $)^{23}$

In addition, Americans now hold or at least admit to - fewer negative assumptions about groups other than their own than they did in the past. Young adults are the most likely to hold "very favorable" opinions of various groups, as Table 1 shows. Certainly, Americans have learned over the past few decades that it is politically and socially inappropriate to express negative stereotypes; thus, some of these "very favorable" opinions are probably insincere. ${ }^{24}$ Nevertheless, we have found no reliable evidence showing that young people are more likely than older adults to give a socially desirable response instead of a sincere one. So it seems reasonable to conclude that, in general, young adults hold more positive images of other groups than do older adults.

Daily life can bring the results of rather sterile survey data to life. At a high school senior prom in Walnut, California, a Thai dances with an African American, while a white, black, and Latino all dance with one another. "Isn't it like this everywhere now?" asks one of the dancers. ${ }^{25}$ Second-generation immigrant young adults in New York, more jaded than high school seniors, perceive plenty of discrimination; but for them, too, "cultural traditions collide, merge, and coexist.... These young people... are often proud of their bicultural abilities." 26

Whether or not they get along with one another, children and young adults are growing up in a world that their grandparents could not have fathomed. About 40 percent of public school students in New York City live in a home in which a language other than English is spoken. The school system translates documents for parents into Spanish, French, German, Chinese, Japanese, Urdu, Persian, Hindi, Russian, Bengali, Haitian Creole, Korean, and Arabic. It teaches students who speak 167 languages - no surprise given that they come from 192 countries. ${ }^{27}$ According to Montgomery (Md.) College President Charlene Nunley, community colleges are making similar adjustments:

When you change in this diverse way, you have to fundamentally change your institution. You have to change the language skills of your frontline people in admissions, registration and records. You have to create international student offices. You have to change the art so people feel their
Jennifer L.

Hochschild,

Vesla M.

Weaver

\& Traci

Burch 
Destabi- Table 1

lizing the Percent of Adults with "Very Favorable” Opinions of Various Racial or Ethnic Groups, 2007 American

\begin{tabular}{|c|c|c|c|c|}
\hline & $\begin{array}{c}\text { White } \\
\text { Respondents }\end{array}$ & $\begin{array}{c}\text { Black } \\
\text { Respondents }\end{array}$ & $\begin{array}{c}\text { Latino } \\
\text { Respondents }\end{array}$ & $\begin{array}{c}\text { Total } \\
\text { Respondents }\end{array}$ \\
\hline $\begin{array}{l}\text { Opinion about Whites } \\
18 \text { to } 29 \text { years } \\
30 \text { to } 44 \text { years } \\
45 \text { to } 59 \text { years } \\
60+\text { years }\end{array}$ & $\begin{array}{l}(30 \%) \\
(34) \\
(31) \\
(29)\end{array}$ & $\begin{array}{l}28 \% \\
26 \\
21 \\
25\end{array}$ & $\begin{array}{l}46 \% \\
44 \\
40 \\
33\end{array}$ & $\begin{array}{l}34 \% \\
33 \\
28 \\
\mathbf{2 8}\end{array}$ \\
\hline $\begin{array}{l}\text { Opinion about Blacks } \\
18 \text { to } 29 \text { years } \\
30 \text { to } 44 \text { years } \\
45 \text { to } 59 \text { years } \\
60+\text { years }\end{array}$ & $\begin{array}{l}\mathbf{2 7} \\
\mathbf{3 1} \\
\mathbf{2 4} \\
\mathbf{2 0}\end{array}$ & $\begin{array}{l}(38) \\
(41) \\
(41) \\
(38)\end{array}$ & $\begin{array}{l}47 \\
35 \\
\mathbf{3 8} \\
\mathbf{3 5}\end{array}$ & $\begin{array}{l}\mathbf{3 7} \\
\mathbf{3 4} \\
\mathbf{3 1} \\
\mathbf{2 6}\end{array}$ \\
\hline $\begin{array}{l}\text { Opinion about Latinos } \\
18 \text { to } 29 \text { years } \\
30 \text { to } 44 \text { years } \\
45 \text { to } 59 \text { years } \\
60+\text { years }\end{array}$ & $\begin{array}{l}19 \\
29 \\
21 \\
18\end{array}$ & $\begin{array}{l}28 \\
26 \\
22 \\
20\end{array}$ & $\begin{array}{l}(60) \\
(57) \\
(51) \\
(49)\end{array}$ & $\begin{array}{l}34 \\
33 \\
24 \\
20\end{array}$ \\
\hline $\begin{array}{l}\text { Opinion about Asians } \\
18 \text { to } 29 \text { years } \\
30 \text { to } 44 \text { years } \\
45 \text { to } 59 \text { years } \\
60+\text { years }\end{array}$ & $\begin{array}{l}30 \\
34 \\
25 \\
22\end{array}$ & $\begin{array}{l}28 \\
25 \\
21 \\
20\end{array}$ & $\begin{array}{l}42 \\
41 \\
37 \\
26\end{array}$ & $\begin{array}{l}33 \\
32 \\
25 \\
22\end{array}$ \\
\hline
\end{tabular}

Figures in boldface indicate decrease in "very favorable" opinions with increasing age. Figures in parentheses indicate respondents' views of their own group. "Other" respondents not included. Source: Authors' analyses of data from the Pew Research Center, "Racial Attitudes in America," September 5 - October 6, 2007 (Pew Research Center for the People and the Press, 2007), http://pewsocialtrends.org/assets/pdf/Race.pdf.

culture is represented. You have to change the food - fundamentally change the way you do business.

Even this list is incomplete. Nunley continues by observing, "[Y]ou've got to have people on your campus that your diverse students can identify with. You've got to have people who understand their issues and their cultures....It's not good enough to say, 'There's nobody out there; I can't find anyone.' You've got to find them." 28

Finally, long-standing and deeply embedded explanations for the old American racial order, in which whites held most of the best positions and blacks held most of the worst positions, are being transformed even as the relative 
Percent of Respondents Agreeing to Certain Explanations for Racial Socioeconomic Inequality, by Age and Across Cohorts, 1985 to 2008

\begin{tabular}{|c|c|c|c|c|c|}
\hline \multirow[b]{3}{*}{ Year } & \multirow[b]{3}{*}{ Age } & \multicolumn{4}{|c|}{ Inequality is Due To: } \\
\hline & & \multicolumn{2}{|c|}{ Less Inborn Ability } & \multicolumn{2}{|c|}{ Lack of Willpower } \\
\hline & & Whites & Blacks & Whites & Blacks \\
\hline \multirow[t]{4}{*}{1985 to 1988} & 18 to 29 & 13 & 9 & 53 & 32 \\
\hline & 30 to 44 & 13 & 6 & 57 & 30 \\
\hline & 45 to 59 & 24 & 25 & 64 & 41 \\
\hline & $60+$ & 36 & 30 & 74 & 48 \\
\hline \multirow[t]{4}{*}{2004 to 2008} & 18 to 29 & 4 & 14 & 46 & 49 \\
\hline & 30 to 44 & 6 & 11 & 48 & 47 \\
\hline & 45 to 59 & 6 & 7 & 47 & 39 \\
\hline & $60+$ & 15 & 19 & 58 & 40 \\
\hline
\end{tabular}
have a large enough sample size of blacks. Source: Authors' analysis of GSS, various dates.

positions themselves are (more slowly) shifting. Since 1977, the General Social Survey has asked respondents for explanations of racial inequality in socioeconomic position. Two of the standard four response options - "less inborn ability" and "lack of motivation or willpower" - clearly make negative attributions to blacks. Comparing responses across decades enables us to see both differences by age at a single point in time and cohort change over time.

Younger respondents are almost always less likely than older ones to attribute blacks' lower status to lack of ability or lack of motivation. ${ }^{29}$ However, disaggregating the data by years reveals a fascinating pattern of cohort change, particularly among blacks. Table 2 shows the results. In the early period, pejorative attributions to blacks rose with age in both races. And with only one exception, within each age group whites expressed more negative views of blacks. In the current period, older whites remain more willing than younger whites to express negative stereotypes, although the absolute levels have declined. Now, however, younger blacks are almost as willing as older ones (in one case), or more willing (in the other case), to attribute socioeconomic differences to blacks' own failings. Most important, in one case, the views of the two youngest groups of adults are converging and, in the other case, the views of all but the oldest group of adults are converging, in explanations of racial inequality. With one exception, the differences between the oldest and youngest adults within a race are now greater than the differences between the two races in a given age group. ${ }^{30}$

Not everything is changing. Old-fashioned racism has not disappeared, as FBI reports of hate crimes, incidents of daily 
Destabi- discrimination, and hostility to even lelizing the gal immigrants make clear. Newer, more American
Racial Order racial domination (often described as laissez-faire, implicit, or symbolic racism) have partly replaced overt Jim Crow forms of control. ${ }^{31}$ And not all forms of destabilization will bring racial justice and equality closer. Without a clear and demonstrable villain, it is very difficult for young people of color and their white allies to understand how racial domination - legacies of the past as well as continuing practices in the present - still constrains their lives. Without group solidarity, if not identity, ${ }^{32}$ many young black or Latino men in poor inner-city neighborhoods will lack the allies and groupbased resources that they desperately need in order to have any chance of conventionally defined success.

Still, American young adults live in a different world from that of the 1960s, a decade that witnessed civil rights struggle, initiation of a new wave of immigration, and first steps toward affirmative action, school desegregation, electoral equality, and immigrants' rights. This generation is more likely to come into interracial contact both voluntarily (choosing more diverse friends, networks, partners, neighborhoods) and involuntarily, given demographic changes. They can hardly help but do so: "four out of 20 children and young adults are minorities, compared with three out of 10 baby boomers and only two out of 10 seniors. New-immigrant minorities... are both younger and more likely to have children than the native White population." Non-Hispanic whites younger than six years old will be in the minority by 2021 ; eighteen- to twenty-nine-yearold non-Hispanic whites will be in the minority by 2028 . Hispanics will then comprise more than a quarter of young adults, and blacks will comprise 13 per- cent. (In contrast, whites older than sixty-five will make up about 60 percent of their age cohort through 2050.)33

Partly through these encounters, and partly because of institutional and attitudinal change, members of this generation will have more leeway to choose their own racial identities, and to change those identities if they want to. Race will be less of a determinant in a young adult's life chances than it was for his or her parents. The old racial memory of marches, fire hoses, and boycotts on behalf of farm workers are being replaced with the burning towers of 9/11, the New Orleans Superdome of 2005, and the 2008 election night euphoria in Grant Park, Chicago. Those images are equally powerful, but their collective impact is more confusing. The American racial order is becoming less and less stable in a variety of ways. That reality clearly leads to dangers, but on balance, we concur with Toni Morrison's report of "guarded optimism": "Guarded. Because the young people I talk to are just different. They're not hanging on to the powerful stories. They're just marching along, marrying who they want to marry. They are not like my generation or even the generation right after me."34 
* Contributor Biographies: JENNIFER L. HOCHSCHILD, a Fellow of the American Academy since 1996, is the Henry LaBarre Jayne Professor of Government, Professor of African and African American Studies, and Harvard College Professor at Harvard University. She is author of The American Dream and the Public Schools (with Nathan Scovronick, 2003) and Facing Up to the American Dream: Race, Class, and the Soul of the Nation (1995). Her current book project, coauthored with Vesla Weaver and Traci Burch, is tentatively titled "Transforming the American Racial Order: Immigration, Multiracialism, DNA, and Cohort Change." At present, she is the John R. Kluge Chair of American Law and Governance at the Library of Congress.

VESLA M. WEAVER is an Assistant Professor of Politics at the University of Virginia. She has published articles in American Political Science Review, Perspectives on Politics, Political Behavior, Studies in American Political Development, and Social Forces. Her first book, Frontlash: Civil Rights, the Carceral State, and the Transformation of American Politics, is forthcoming from Cambridge University Press. Her current book project is "Political Consequences of the Carceral State" (with Amy Lerman).

TRACI BURCH is an Assistant Professor of Political Science at Northwestern University and a Research Professor at the American Bar Foundation. Her publications have appeared in Political Behavior, Law and Society Review, and the Du Bois Review. Currently, she is completing a book manuscript, "Punishment and Participation: How Criminal Convictions Threaten American Democracy.”

1 Peniel Joseph, "Our National Postracial Hangover,” The Chronicle of Higher Education, July 27, 2009; Steve Cohen, Letter to the Editor, The New York Times, September 18, 2009; Ellis Cose, "Red, Brown, and Blue," Newsweek, January 11, 2010.

2 There is no sharp distinction between younger and older individuals; on average, the evidence suggests a division around age thirty, but the changes we describe are better understood as a continuum than as a dichotomy.

3 Jennifer Hochschild and Brenna Marea Powell, "Racial Reorganization and the United States Census 1850 - 1930: Mulattoes, Half-Breeds, Mixed Parentage, Hindoos, and the Mexican Race," Studies in American Political Development 22 (1) (2008): 59-96; Brenna Powell, A New Comparative Agenda for Ethno-Racial Politics (Cambridge, Mass. : Harvard University Government and Social Policy Program, 2010).

4 A good recent example of this argument is in Christina Beltran, The Trouble with Unity: Latino Politics and the Creation of Identity (New York: Oxford University Press, 2010).

5 The first item is from Pew Research Center, "Racial Attitudes in America” (Washington, D.C. : Pew Research Center for the People and the Press, 2007), http://pewsocialtrends .org/assets/pdf/Race.pdf. The second item is from Fredrick C. Harris and Gary Langer, "Survey on Race, Politics, and Society" (Center on African-American Politics and Society, Columbia University, and the ABC Polling Unit, September 2008).

${ }^{6}$ All data in this paragraph are from Pew Research Center, Marrying Out: One-in-Seven New U.S. Marriages Is Interracial or Interethnic (Washington, D.C. : Pew Research Center for People and the Press, 2010).

7 Lauren Gilbert, “Citizenship, Civic Virtue, and Immigrant Integration: The Enduring Power of Community-Based Norms," Yale Law and Policy Review 27 (Spring 2009): 374, $380-381$.

8 Jiannbin Shiao and Mia Tuan, "Korean Adoptees and the Social Context of Ethnic Exploration," American Journal of Sociology 113 (2008): 1023.

9 Brian Duncan and Stephen Trejo, Intermarriage and the Intergenerational Transmission of Ethnic Identity and Human Capital for Mexican Americans (Bonn, Germany: Institute for the Study of Labor, 2008), 26. 
Destabi- 10 Darryl Pinckney, "What He Really Said,” The New York Review of Books, February 26, $2009,10$.

American 11 "Leaders of the New School," Essence, February 2009, 106-107.

Racial 12 Kenneth Cooper, "Young, Black, and in the Running," The Boston Globe Magazine, July 19, Order 2009, 19. See also Gwen Ifill, "Nothing Unique About It,” TIME, September 1, 2008, 54.

13 David Bositis, Changing of the Guard: Generational Differences among Black Elected Officials (Washington, D.C. : Joint Center for Political and Economic Studies, 2001).

14 Peter Levine, Constance Flanagan, and Les Gallay, The Millennial Pendulum: A New Generation of Voters and the Prospects for a Political Realignment (Washington, D.C. : New America Foundation, 2009), 5.

15 Michael Lewis-Beck, “The Economy, Obama, and the 2008 Election,” PS : Political Science \& Politics (July 2009): 481.

16 Alan Abramowitz, "Barack Obama and the Transformation of the American Electorate," August 25, 2009, http://papers.ssrn.com.

17 John Griffin and Brian Newman, Minority Report: Evaluating Political Equality in America (Chicago: University of Chicago Press, 2008); Craig Volden and Alan Wiseman, "Legislative Effectiveness in Congress" (Department of Political Science, Ohio State University, 2009). Alarmingly, some evidence suggests that many younger blacks and Hispanics exhibit very high levels of political alienation and nihilism; see Cathy J. Cohen, Democracy Remixed: Black Youth and the Future of American Politics (New York: Oxford University Press, 2010).

18 Robert Crutchfield, Martie L. Skinner, Kevin P. Haggerty, Anne McGlynn, and Richard F. Catalano, "Racial Disparities in Early Criminal Justice Involvement," Race and Social Problems 1 (2009): 218 - 230; Wesley Skogan, "Asymmetry in the Impact of Encounters with Police," Policing and Society 16 (2) (2006): 99-126.

19 Michael Powell, "Profiles of Men Who 'Fit the Description,'” The Washington Post, December 14, 2006.

20 Immigration and Nationality Act, section 287 (g) 1996.

21 Government Accountability Office, Immigration Enforcement: Better Controls Needed over Program Authorizing State and Local Enforcement of Federal Immigration Laws, January 2009, http://www.gao.gov/new.items/do9109.pdf.

22 Pew Hispanic Center, Illegal Immigration Backlash Worries, Divides Latinos (Washington, D.C. : Pew Research Center, 2010), http://pewhispanic.org/files/reports/128.pdf.

23 Authors' analyses of Pew Research Center, Trends in Political Values and Core Attitudes: 1987 - 2009: Independents Take Center Stage in Obama Era (Washington, D.C.: Pew Research Center for the People and the Press, 2009), http://people-press.org/report/517/ political-values-and-core-attitudes.

24 Nevertheless, one might argue that a racial order has changed in important ways if more and more people who once used derogatory group stereotypes no longer feel free to express them publicly.

25 Marie O’Connor, “Learning to Look Past Race,” Los Angeles Times, August 25, 1999.

26 Philip Kasinitz, John Mollenkopf, Mary Waters, and Jennifer Holdaway, Inheriting the City: The Children of Immigrants Come of Age (New York and Cambridge, Mass. : Russell Sage and Harvard University Press, 2008), 273, 342.

27 Leanna Stiefel, Amy Schwartz, and Dylan Conger, "Language Proficiency and Home Languages of Students in New York City Elementary and Secondary Schools," February 2003, http://ssrn.com/abstract=1064581.

28 Charlene Nunley, quoted in David Pluviose, "Study: Most Community Colleges Not Fully Prepared for Demographic Shift,” Diverse, May 18, 2006, 10 - 11. 
29 Not surprisingly, there is a strong correlation between these two attributions. We found no significant age difference in the likelihood of explaining status differences by discrimination or lack of education.

30 These results are not unique. We also found this general pattern of attitudinal or explanatory convergence in the 2000 s among young adults in other items on other surveys. The same sort of convergence across races does not appear among older adults.

${ }^{31}$ Lawrence Bobo, James Kluegel, and Ryan Smith, "Laissez-Faire Racism: The Crystallization of a Kinder, Gentler Antiblack Ideology," in Racial Attitudes in the 199os: Continuity and Change, ed. Steven Tuch and Jack Martin (Westport, Conn. : Praeger, 1997), 15-43; Donald Kinder and Lynn Sanders, Divided by Color: Racial Politics and Democratic Ideals (Chicago: University of Chicago Press, 1996); Nilanjana Dasgupta, Debbie McGhee, Anthony Greenwald, and Mahzarin Banaji, “Automatic Preference for White Americans : Eliminating the Familiarity Explanation," Journal of Experimental Social Psychology 36 (3) (2000): 316-328; Brian Nosek, Frederick Smyth, Jeffrey Hansen, Thierry Devos, Nicole Lindner, Kate Ranganath, Colin Tucker Smith, Kristina Olson, Dolly Chugh, Anthony Greenwald, and Mahzarin Banaji, "Pervasiveness and Correlates of Implicit Attitudes and Stereotypes," European Review of Social Psychology 18 (1) (2007): 36-88.

32 Tommie Shelby, We Who Are Dark: The Philosophical Foundations of Black Solidarity (Cambridge, Mass. : Belknap Press of Harvard University Press, 2005).

33 William Frey, “The Racial Generation Gap,” Milken Institute Review (2007): 16 - 17 ; William Frey, "The Census Projects Minority Surge,” Brookings Institution, January 7, 2010.

34 “Toni Morrison,” AARP, January - February 2009, 26, 28. 